\title{
Políticas de la vergüenza y la exclusión: el sujeto mestizo en Parias zugun de Adriana Pinda*
}

Politics of shame and exclusion: the crossbred subject in Adriana Pinda's Parias zugun

\author{
Fernanda Moraga-García
}

Centro de Estudios Avanzados (CEA), Universidad de Playa Ancha

Correo electrónico: fernanda.moraga@upla.cl

En el presente artículo se abordan las estrategias políticas que Adriana Pinda desenvuelve en su libro Parias zugún, para posicionar una comunidad de resistencia al pacto histórico implícito entre los poderes patriarcales-indígenas y patriarcales-colonialistas. Esta comunidad se forma fundamentalmente a partir de un heterogéneo "matrilinaje" en el cual la resignificación histórica de la figura de la Malinche es fundamental. De este modo, es significativa, para este estudio, la construcción política tanto de la condición mestiza y paria, como de la vergüenza y la exclusión que manifiesta y legitima la sujeto de los poemas.

Palabras clave: mestiza, mapuche, paria, exclusión, Malinche.

In this article the political strategies that Adriana Pinda performs in his book Parias zugun are considered in order to situate a community's resistance to the implicit historic pact between the patriarchal-indigenous and the patriarchal-colonialist powers. This community is formed mainly from a heterogeneous "matrilineality" where the historical resignification of the Malinche figure is essential. Thus, for this study, it is relevant the political construction of both the crossbred and pariah conditions as well as the shame and exclusion that manifest and legitimate the subject of these poems.

Key words: crossbred, mapuche, pariah, exclusion, Malinche.

Agradecimientos al Proyecto DICYT n 031551ND. Co-Investigadora. Universidad de Santiago de Chile, USACH. 
Sean ustedes

mi lengua viva, de muerta.

G. Mistral

¿Y quién no tiene un amor? ¿Y quién no goza entre amapolas? ¿Y quién no posee un fuego, una muerte, un miedo, algo horrible, aunque fuere con plumas aunque fuere con sonrisas? Abrid la boca para recibir la hostia de la palabra herida la hostia angustiada y ardiente...

V. Huidobro

\section{Alrededor de la sujeto pindariana}

La poesía de Adriana Pinda se inserta dentro de un campo literario (Bourdieu 1989) mapuche actual, que concibe la escritura poética como posición política en cuanto se vincula, desde una perspectiva diferenciadora e intercultural, con identidades que no hacen concesiones a estereotipos culturales. Nos referimos a un corpus, tanto de mujeres como de hombres, que libera las categorías impuestas a la poesía y al sujeto mapuche, en relación a un origen y a un anclaje "étnicamente" correcto (Moraga 2009a). Pensamos en estos momentos en poetas, además de Adriana Pinda, como Roxana Miranda Rupailaf, Jaime Huenún, Liliana Ancalao, Ivonne Coñuecar, Bernardo Colipán, David Añiñir, Maribel Mora Curriao y Yeny Díaz Wentén, solo por citar algunos nombres.

Desde esta perspectiva, las estrategias discursivas que encontramos en los textos permiten reflexionar en torno a una conciencia identitaria que es, permanentemente, resignificada. Las transformaciones que puede sufrir la voz enunciativa posibilitan la puesta en escena de las tensiones y conflictos de un sujeto que se asume mestizo y mapuche. De este modo, la poesía a la que hacemos referencia ejercita una política del sujeto que emerge identitariamente atravesada, plural y fronteriza, por lo tanto, interétnica e intercultural.

Dentro de esta problemática de un sujeto poético de fronteras culturales, sociales e históricas es que, sin duda, adquiere sentido la experiencia del exilio y el extrañamiento como territorio simbólico de un "entre-medio" (Bhabha 2002). Las diferentes estrategias discursivas enfatizan el posicionamiento de una experiencia mestiza como eje central del discurso poético. Con esto, esta poética mapuche diluye cualquier intento de involucrar maniqueísmos, ya sean étnicos y/o colonialistas. Tiene que ver con escrituras que, con diversos matices, reescriben la historia personal y colectiva. Son historias parciales en las cuales emergen diferentes espacios de representación: la memoria, el cuerpo, la muerte, la lengua, la historia privada y colectiva, la pertenencia y despertenencia, el mestizaje, las fisuras existenciales y culturales y las discontinuidades de los discursos de dominio (Moraga 2006). Es así como la poesía mapuche actual, instala procesos complejos de conocimiento que se derivan de una experiencia de "contactos, contaminaciones, préstamos y pérdidas (Spíndola 2011: 68) que ha tenido el pueblo mapuche. 
Es este el complejo y profuso territorio cultural que contiene la producción poética de Adriana Pinda. Los textos de la poeta acuden a una enunciación en contradicción que se da, básicamente, a través de la tensión entre pasado y presente. Por lo mismo, su escritura tiene que ver, entre otras cosas, con la tensión entre oralidad y escritura (Carrasco 2005), tensión que sin lugar a dudas corresponde a una estrategia política que se emparenta con lo que Mabel García propone como "retradicionalización cultural" (2012: 51). García expresa -en un análisis sobre el libro Üi (2005) de Adriana Pinda-, que el arte mapuche actual persigue posicionar y visibilizar una producción estética con "identidad propia diferenciada" (51). Para lograr este objetivo, la autora afirma que una de las estrategias principales que se observa en la práctica artística mapuche es, como ya decíamos, la “retradicionalización cultural”. Tal identidad, además, sería empujada por las relaciones asimétricas que la sociedad chilena ha mantenido, hasta hoy, con la sociedad mapuche. De esta forma, la poesía de Pinda se manifiesta, tal como lo afirma Spíndola, como "un territorio de enunciación de una conciencia plural, una actividad que irrumpe el silencio del pasado y lo llena de voces disonantes” (2011: 71).

La escritura de Pinda, entonces, es una propuesta estética no celebrativa, sino que se postula en el flujo de identidades que irrumpen en la colonialidad del conocimiento, porque trae representaciones de una sujeto desplazada por su condición mestiza. En otras palabras, su poética se instala en las discontinuidades del poder esencialista, colonialista y patriarcal.

Esto me hace repensar la mestizada discursiva no solo de su primer libro Üi o de la selección de poemas "Ralum" (2000) o de su texto poético-narrativo "Williche,

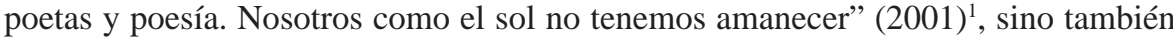
del texto "Cartas al país mapuche" (2014)². Leamos un fragmento de esta misiva:

Mi pewma vino a mí, como tantas veces, barriendo toda duda en mi interior, sanando aquello resquebrajado y weküfeano, que la diversidad epistémica, en la que seres como yo viven, hace por decir lo menos, sospechoso, lo que algunos llaman "colonialismo" y “colonialidad" [...].

[...] más allá del rol que me han heredado mis extraviadas abuelas machi, vapuleadas y denostadas, una y otra vez, por el sintomático "mapuchómetro" contemporáneo, porque mi apellido "Pinda" (picaflor, decir), no está escrito ni en crónicas de guerra ni en memorias de grandes caciques, por lo que no puedo jactarme ni justificarme en mi linaje celeste, tal vez en la poesía, y porque soy una machi champurria, a mala honra, solo mapuche de madre, lo que ya me hace "ambigua"; y más aún, poeta y profesora, "machi escueliá" como dicen las papay, una anomalía, algo raro e indefinido.

A pesar de mi misma [...] el único tuwün y küpan posible para los seres como yo, es la palabra. (Paredes Pinda 2014: s/p)

Existe otro poemario de la autora llamado "Witral ñi rayen / La flor del telar", publicado en la revista Ciudad Circular el año 2005. Se trata de un breve poemario compuesto por pequeños poemas que asumen un punto de vista enunciativo, fundamentalmente, intracultural. A esto hay que agregar que, hasta ahora, es el único texto bilingüe de la autora, es decir, cada poema en mapudungun tiene su traducción al español.

Se trata de un texto que Adriana Pinda difunde por internet a propósito del encarcelamiento y condena de la machi Millaray Huichalaf Pradines por parte de la (in)justicia chilena y en el cual la autora también reflexiona sobre la compleja situación política actual del pueblo mapuche. La machi fue detenida en enero de 2013, y luego condenada en noviembre del mismo año a 61 días de presidio remitido por presunta "encubridora" del incendio que afectó a una vivienda del fundo Pisu Pissué, en la comuna de Río Bueno. Todo esto dentro de un procedimiento que estuvo cargado de anomalías legales desde su comienzo. 
La cercanía que tienen estos párrafos con el libro Parias zugun es notable. La sujeto del poemario contiene todos los elementos mencionados en estos fragmentos: 1) es el pewma-la visión, el vaticinio-, un saber ancestral que guiará a la sujeto poética en su propio camino de subjetivación; 2) es la genealogía de una comunidad "anómala" la que construye a la sujeto a partir de su condición mestiza y, por lo tanto, 3) la única posibilidad de articular el proceso de su identidad individual, social y territorial -su tuwün y küpan- es en un habla paria ${ }^{3}$.

Es así como esta sujeto pindariana surge, asumiendo un doble apego y, por lo mismo, una doble problemática. Por una parte, emerge lo que podríamos denominar un "apego colonial”, dado a través de la articulación entre su fascinación por la palabra escrita -poética- y su "vergüenza” mestiza. Por otra parte, vemos su afecto amoroso por el mapudungun, por el zugu y todo el universo comunicativo que esto significa para el mapuche en su identidad singular y colectiva, apego que igualmente se manifiesta vinculado a su "vergüenza” mestiza. Ambas condiciones de la identidad se dan tanto a nivel individual como comunitario y apelan, además, a una descolonización y a una despatriarcalización (Paredes 2013) de historias singulares y colectivas. A partir de estas direcciones del discurso, la voz enunciativa busca conseguir el sentido de su “yo” por medio de la problematización de ambos apegos. La sujeto asume aquí su condición mestiza, la que da origen al posicionamiento de su parias zugun.

\section{AlREDEDOR DE LA MESTIZADA PINDARIANA}

Parias zugun, de igual forma que la mayor parte de la escritura de Adriana Pinda, asume una enunciación política que se sustenta en una condición mestiza. Al señalar una identidad mestiza, lo estamos haciendo en el sentido de que el concepto de mestizo y “mestiza” no solo da a conocer diferentes elementos sociales y culturales que inciden de manera compleja y diversa en la configuración de sujeto en América Latina, sino que, fundamentalmente, porque esta noción deja al descubierto las contradicciones que estos elementos traen al proceso identitario. Esto genera, además, que este/a sujeto proyecte un pensamiento y una visión de mundo mestiza, por lo tanto, heterogénea y problemática. En este sentido, coincidimos con Sergio Mansilla, cuando afirma que

un sujeto lírico mestizo, menos que dar respuestas a una situación de conflicto cultural-político, su quehacer se perfila más como un doloroso desnudamiento de sí mismo haciendo visible sus ‘impurezas’ culturales, sus líneas de fuga, sus descentramientos ontológicos, su provisionalidad identitaria, su dificultad para (auto)clasificarse dentro de ciertos campos etnoculturales predefinidos" (2011: 69).

Es en este sentido que también proponemos la noción de mestizada, la que refiere no solo al sujeto singular, sino que, al mismo tiempo, señala un espacio políticocolectivo y/o comunitario mestizo, donde "los signos pueden ser apropiados,

\footnotetext{
El tuwün y el küpan son la base de la identidad individual, social y territorial de los mapuche. El tuwün, es el conocimiento del lugar o territorio geográfico de origen de la persona y el küpan el conocimiento de la ascendencia, origen y linaje, de donde proviene la persona. Esta genealogía, actualmente, se advierte en los apellidos, los que antes de la colonización correspondían a los nombres.
} 
traducidos, rehistorizados y vueltos a leer” (Bhabha 2002: 58). Por lo tanto, la mestizada se construye como una “cartografía de las políticas de la interseccionalidad” (Brah 2011: 40) cultural, social e histórica que se comparten en una comunidad. En su estrecha relación con una concepción política del mestizaje, como la que hemos anotado, la mestizada posiciona fuerzas de alteridad y resistencia, convirtiéndose así en "la posibilidad de una perspectiva radical desde la que [se puede] ver, crear, inaugurar alternativas, nuevos mundos” (Hooks 2004: 157) ${ }^{4}$. Se trata, entonces, de una localización política de cruce de fronteras, en la cual se encuentran enunciaciones contra-colonialistas y no-esencialistas. En efecto, la mestizada no enfatiza en lo “originario" como un trascendente, sino más bien en los terrenos de la transcripción, del contagio y del tráfico intercultural e interlingüístico (Moraga, 2012).

Las articulaciones descritas entre la mestizada, la identidad mestiza y el espacio mestizo permiten leer el texto de Pinda a partir de algunas tensiones y sentidos que se generan desde la misma complejidad fronteriza de dichas tensiones y sentidos.

El libro Parias zugun se despliega como un solo gran poema, no tiene divisiones o cortes formales o evidentes en capítulos, segmentos o partes. Su antesala -preámbulo le llama la autora-, está compuesto por palabras de la misma poeta que anuncia y saluda la voz de su hija Küyen Trallenko Marina, con quien comparte "el nacimiento de Parias...” y del cual la hija dice:

Expresa [mi madre] su sentir como mapuche [...] dentro de la división de las realidades impuestas en la actualidad y las antiguas y siempre recordadas realidades de nuestra ascendencia, en las que se dificulta hacer favor al tiempo vigente para ser consecuente. (Cit. en Pinda 2014: 5)

Me interesa mencionar esto, ya que es la primera articulación que nos presenta el texto en relación a la formación de una comunidad de mujeres y porque es la primera alusión a uno de los conflictos fundamentales que cruza al poemario: cierta normativa tradicionalista, que actualmente determina identidades mapuches "limpias o puras". ${ }^{6}$

\footnotetext{
Esto corresponde a una traducción mía del fragmento original: "the possibility of radical perspective from which to see and create, to imagine alternatives, new worlds” (Hooks 2004: 157).

De aquí en adelante, en las citas del libro solo se indicarán las páginas, puesto que corresponden a la misma edición.

6 La construcción o la emergencia de estas identidades "puras” en este artículo no se comprenden desde un punto de vista simplificado del concepto de esencialismo, sino que en sus relaciones contextuales. Por lo menos, existen dos líneas que difícilmente corren por caminos paralelos. Existe una perspectiva que hace alusión a una "autenticidad" del sujeto mapuche, en el sentido de aquel sujeto que habla y cultiva una lengua y una cultura "original", fundadas en un pasado ignoto. A esto se suma el ser descendiente de algún héroe de la Guerra de Arauco, de la Ocupación de la Araucanía o de alguna autoridad mapuche. Es necesario tener en cuenta, en este sentido -y aquí la segunda línea a la que me refería-, que esta reetnificación que experimenta una parte de la sociedad mapuche tiene también articulaciones políticas. Al respecto, Fernando Pairicán argumenta: “[...] el incendio de los camiones de una de las firmas empresariales más poderosos en Chile renovó una subjetividad en los Mapuche, perfilándose un nuevo tipo de militante en la transición democrática: el 'mapuchista'. [...] Militante que articuló la subjetividad impulsada por el Consejo de Todas las Tierras, propio de la siembra ideológica que impulsó esta organización desde los 90 [...], con los nuevos postulados que irrumpieron desde la CAM que se expresaron en la revalorización del 'orgullo' de la morenidad, y por lo tanto, enclavando un paso importante en la descolonización del pueblo Mapuche. Con ellos, la cuestión nacional Mapuche se inscribió como parte de una 'oleada' indigenista continental que desde los noventa fue exigiendo el derecho humano de la autodeterminación” (2013: 36).
} 
En el centro del libro está la voz de una sujeto mestiza, no por voluntad, sino que por terribles acontecimientos históricos que estuvieron fuera del alcance en su origen. No se trata simplemente de una sujeto champurria ${ }^{7}$ como consecuencia de un coloniaje sostenido en nuestro continente, sino más bien de la lúcida escenificación de una sujeto que legitima su experiencia expoliada ${ }^{8}$. Estamos ante la narración poética de una tragedia, la que deja al descubierto una insurrecta costura genealógica o de parentesco que desestabiliza códigos identitarios preconcebidos. Ejemplo de ello es la apelación permanente a kallku, a weküfe y a Kanillo ${ }^{9}$ como fuerzas que intervienen en la tragedia del destierro de la sujeto, no como energías transitorias o antagónicas a la misma sujeto, sino que, por el contrario, son parte de ella misma. Es más, la sujeto es una kallku, es parte de la "weküfada” y le ruega a Kanillo. Por lo tanto, estas fuerzas simbólicas refuerzan la legitimación de una experiencia que se configura a partir de una visión de mundo donde no pervive ninguna ortodoxia racial ni cultural.

Es importante comprender, en este sentido, que el libro no nos pone frente a ninguna oposición maniqueísta que reduzca la reflexión a una simple ecuación de purismo versus mestizaje. Por el contrario, percibimos que ambos niveles corresponden a micropolíticas de resistencia (Deleuze y Guattari, 1994). Solo que una incorpora una problemática analítica de las transformaciones históricas en un sentido cosmovisionista y tradicionalista y termina orientando su deseo de resistencia hacia un paradero microesencialista. La otra, la que le interesa a Adriana Pinda y, como dijimos, no actúa por antítesis a la primera, se diseña como respuesta e intervención de un deseo político que se dirige hacia la construcción de nuevos territorios de la subjetividad y de otras formas de experienciar ciertos procesos históricos. Por lo tanto, la resistencia de la sujeto pindariana se construye como una micropolítica que da lugar a diferentes condiciones, diferentes sensibilidades y diferentes prácticas de la subjetividad. En el texto se intentan posicionar los procesos de singularización mestiza dentro del propio horizonte del cual emergen, creando un territorio intracultural divergente de la cadena seriada de la identidad.

Si prestamos atención a la identidad de $k a l k u^{10}$ que revela la sujeto, podemos ver que del mismo modo que la machi requiere de una comunidad dentro de la cual goza de autoridad, confianza y protección, la sujeto kalku que ahora se nos presenta se sitúa de la misma forma, solo que enfrentada a su propia "envidia", la que se complementa con su "vergüenza” mestiza. ${ }^{11} \mathrm{Ni}$ la "envidia” ni la "vergüenza” son

Champurria: mestizo/a.

8 Al ocupar en este estudio el concepto "legitimar", ya sea una experiencia, un sujeto, una comunidad, una cultura, etc., estamos aludiendo a la problemática y contradicción que trae este lugar y no en referencia a lo normalizado y aceptado por los poderes hegemónicos.

$9 \quad$ El espíritu de kallku es, si se quiere, la contra parte de la machi. El o la kallku, en términos generales, sería una fuerza desintegradora que porta una persona y que puede provocar enfermedades, especialmente causadas por la envidia. El weküfe es una energía desestabilizadora del equilibrio existente en el mundo mapuche, produce enfermedades o muerte. La o el kallku tendría un espíritu weküfe. Un poderoso weküfe sería Kanillo, perteneciente a la cosmovisión huilliche. A Kanillo se le reconoce como una fuerza destructora del equilibrio de la sociedad huilliche.

10 Es importante señalar que la escritura anterior de Adriana Pinda, es decir, hasta antes de Parias zugun, está tejida, predominantemente, por la voz enunciativa de la machi, problematizada y mestizada, por cierto, pero posicionada en ella. Sin embargo, ahora la autora nos entrega una voz en la que prevalece la posicionalidad -y también la dignidad- de kalku.

11 Como ya apuntamos en una nota anterior, la fuerza desintegradora que utiliza el kalku o la kalku, proviene del wekufe 
lugares neutros para la autora, sino que se desenvuelven como políticas del sujeto mestizo que vive, por su condición, el destierro interno. Es decir, la sujeto pindariana podría situarse en lo que hoy se denomina “insilio", puesto que se trataría de una identidad quebrantada y desplazada en cuanto su experiencia es reprimida o censurada por la misma sociedad en que vive ${ }^{12}$. Sin embargo, cuando esta contención de experiencia tiende a liberarse puede transformarse en expresión política, ya que aparece en escena la conciencia crítica del extrañamiento. A esto se suma que la sujeto poética -como sujeto kalku-vive su envidia no a partir de lugares comunes como los celos, el rencor o el resentimiento; sino que a partir de sentimientos de intranquilidad, alteración, contradicción y también de soledad e infortunio. Sentimientos que son provocados, y esto es fundamental, por una carencia: la significación de mundo que entrega el mapudungun ${ }^{13}$. En consecuencia, su envidia -su enfermedad, su tragediaes producto de una ausencia que es vital para su supervivencia. Es la pieza clave que empuja a la sujeto a convertirse en paria:

mapuzungun niño abuelo wentru mapuzungun

-“busquelo y no lo hallé”-

lengua del gran amor

me consumí del feroz anhelo

kallku

fui

por rebelión de lenguas

me hice paria (122)

Es significativo cómo el discurso de Parias zugun se moviliza a través de la emergencia de las fuerzas negativas, destructoras o desestabilizadoras de la sociedad mapuche. A partir de este lugar de reverso, el que le aporta significado a su experiencia mestiza, es que surge el deseo de la sujeto y se manifiesta el afecto por su propio universo en mapudungun:

y, fundamentalmente, es alimentada por algún tipo de envidia.

12 El concepto de "insilio" cobra relevancia a partir de fines de los años 90 del siglo XX en adelante, debido a que algunos estudios críticos sobre las últimas dictaduras en el Cono sur comienzan a preocuparse por la figura de aquella persona que, pudiendo haber sido hostigada o perseguida por las dictaduras, y que por diferentes motivos no sale al exilio, vive bajo estos regímenes dictatoriales. De aquí, entonces, que a esta situación política se le denomine insilio. En relación a esto, Naín Nómez plantea que la poesía del insilio, es decir aquella que se produjo dentro de Chile durante la dictadura militar en los años 70, corresponde a una "poesía política". En ella predominaba "el sentido de pérdida, de angustia ante lo impredecible, de atmósferas irrespirables, [lo que se entrecruzó] con una vaga premonición utópica que nunca termina de concretarse” (Nómez 2010: 109).

Esto se relaciona con lo que nos plantea José Quidel: "Dentro de la manera en que los Mapuche entendemos el mundo existe un algo transformador en el pensamiento de las formas en las palabras, ese algo lo denominamos zugu. En él anclan nuestras vidas, nuestro andar, nuestro observar de las diferentes manifestaciones de la vida, de la diversidad de nuestros congéneres. [...] todo aquello que realizamos o no logramos realizar es impulsado por aquello que es denominado zugu. [...]. Zugu es aquello que logra condensarse en pensamiento, que logra manifestarse en palabras, gracias, paradojalmente, a la diversidad de conocimientos y aspectos que estos mismos conocimientos poseen. El zugu se transforma y se manifiesta en sueños, es parte de una dimensión espiritual; es parte de una dimensión terrenal [...]. Entonces podemos expresarlo a través de nuestras formas de hablar. [...] se manifiesta a través de la boca como un aliento y sonido" (Quidel 2015: 38-39) 


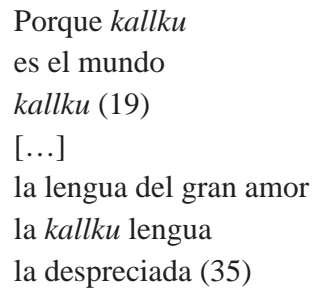

En el mismo sentido de esta alianza con el "mal" -lo que se traduce en una insubordinación a la norma- ${ }^{14}$, es que la sujeto también da forma al presagio de su lengua paria y al proceso de su identidad "contaminada"15. Asimismo, todos estos significados del discurso aparecen vinculados a lo que mencioné más arriba: un relevante matrilinaje. De hecho, ya la dedicatoria que introduce a la lectura del libro es cardinal en este sentido: "A mi madre Marina Pinda Antías, este mi duelo / a la hija de la hija de la hija de la hija...” (9).

Pinda propone una trayectoria comunitaria compleja, la que está compuesta en su mayoría por un núcleo amplio y diverso de mujeres. Se trata de una comunidad ${ }^{16}$ que deshace cualquier intento de universalismo mapuche y, de pasada, occidental, y en la que entran en juego la ética, la justicia, la experiencia, el diálogo, la diferencia y la resistencia de un sujeto mapuche y mestizo. ${ }^{17}$

Junto a esta resistencia a la discriminación, se presenta una posición de género que es vista como "una categoría política relacional de denuncia” (Paredes 2013: 62). Al recuperar una memoria -pasada y actual-, que congrega desde tatarabuelas, mujeres mapuche y no mapuche contemporáneas, hasta representaciones de relatos de origen; Pinda pone en juego una interpretación propia de la exclusión de género. Para la feminista aymara-boliviana Julieta Paredes existe lo que ella llama el "entronque patriarcal” que se relaciona con el reconocer que existió históricamente una alianza, si bien jerarquizada, entre el patriarcado precolonial y el occidental

14 A partir de una apuesta escritural diferente, la poética de Roxana Miranda Rupailaf también asume una íntima proximidad con subjetividades subversivas, las que están al reverso de la historia oficial masculinizada.

15 Uso el concepto de "contaminación”, no en el sentido de una calificación positiva o negativa del sujeto mestizo, ni de oposición antinómica entre impuro/puro. Lejos de eso y de cualquier mirada binaria, me interesa por su posibilidad de disidencia e interrupción de lo normado o esperado "naturalmente" por los discursos normalizadores. O lo que Foucault (...) llama: el "enrarecimiento del discurso". Es decir, "reconocer un corte, un enrarecimiento del discurso [significa que] los discursos deben ser tratados como prácticas discontinuas que se cruzan, a veces se yuxtaponen, pero que también se ignoran o se excluyen” (Foucault 1992: 32-33). De aquí, entonces, que su uso se encuentre entre comillas.

16 En este colectivo también existen figuras masculinas ancestrales, contemporáneas y simbólicas, las que no responden a un lugar menor o jerarquizado respeto de sus pares femeninas. Solo que la fuerza filial mayor está depositada en un colectivo de mujeres. Entre las representaciones masculinas que inscribe el heterogéneo colectivo de la sujeto poética se encuentran: Dionisio Trafián, Huenteyao, Kallfuküra, Leonel Lienlaf, Kanillo, Walt Whitman, Lucho Pinda, Aureliano Buendía, Millalobo, Gonzalo Rojas.

17 Me parece que en esta perspectiva de comunidades de diferenciación dentro de la poesía de mujeres mapuche, la producción de Adriana Pinda podría aproximarse no tan solo a la propuesta de Roxana Miranda Rupailaf, como afirmo en una nota anterior, sino que también a propuestas como las de Yeny Díaz Wentén, Liliana Ancalao, Maribel Mora Curriao e, incluso, de Ivonne Coñecar. Planteo esto a partir de que en la poesía de estas autoras se ponen en escena diferentes subjetividades individuales y comunitarias que entregan nuevos recorridos de lectura en relación a las identidades mapuches actuales. 
(Paredes 2013). Hegemonía que se instala en el momento de la colonización como un contrato naturalizado entre poderes indígenas y poderes españoles, y el que solo puede ser superado, según Paredes ${ }^{18}$, atendiendo a una conciencia de géneroindígena. Es a través de esta conciencia política, que sería posible "descolonizar" y “despatriarcalizar” las relaciones de género en el presente ${ }^{19}$. Esta perspectiva del emergente feminismo indígena en América Latina en los últimos años, nos permite visualizar la relevancia de la figura de la Malinche en la filiación que se realiza en el poemario y a lo que me voy a referir más adelante.

Es indudable que toda la escritura de Adriana Pinda está atravesada por la construcción de un tejido de parentesco -quizás podríamos hablar de un küpan o küpalme a nivel simbólico-poético, si se quiere- particular y diferenciador, que se nutre como ya se indicó, de una filigrana de mujeres. Es claro que en Parias zugun este "küpalme" matrifilial se manifiesta como un espacio abierto y múltiple, porque en él participan y confluyen diversas subjetividades y diferentes tiempos que también actúan como micropolíticas de la resistencia. Así, encontramos la huella familiar de la hija y la madre (Küyen y Marina), de la abuela (Yolanda), de la bisabuela (Asunción) y de la tatarabuela (Filipa) de la sujeto poética. Hallamos también el rastro poético y antiguo de las ülkantufe -poetas orales-, tales como: Amalia Aillapan, Rosario Tripaiantü, Antonia Kaiún y Teresa Weitra ${ }^{20}$. También están las poetas mapuche actuales: Roxana Miranda Rupailaf, Graciela Huinao, Faumelisa Manquepillán. De igual forma, encontramos a las otras, las winkas, que también contienen la sanación de su lengua herida: Alfonsina Storni, Gabriela Mistral -Lucila-, Juana Inés de la Cruz, Alejandra Pizarnik y Safo. No quedan fuera la dantesca Beatriz, la macondiana Remedios la Bella, la pitonisa griega Casandra, la loca Ruth Marigual y la hechicera

18 Julieta Paredes y también otras feministas indígenas, fundamentalmente aquellas que proponen un feminismo comunitario, postulan una perspectiva de género disidente del feminismo occidental o hegemónico, principalmente, porque este último apelaría a un sujeto individual y no a un sujeto comunitario que al mismo tiempo es individual. Para la "Corporación de Mujeres Mapuche Aukinko Zomo", la identidad de pueblo sería una de las identidades que la categoría de género occidental no considera, argumentado que quienes la hicieron visible, por primera vez, fueron las feministas negras en Estados Unidos. Para esta organización mapuche, esta condición, junto a otras identidades como la clase social, la raza y la sexualidad, se definen a partir de "la interdependencia entre individualidad y colectividad" (Mercado Catriñir et al. 2015: 12).

19 Actualmente, estas dos fuerzas hegemónicas continúan su dominio a través de otras máscaras de coacción. Así lo explican algunas feministas mapuche, llamando a este influjo de dominación un poder de "doble faz": "La violencia externa o estructural, ejercida desde el estado como desde los proyectos políticos gobernantes, a través de la masificación de las distintas invasiones e intervenciones, donde desde proyectos concebidos como 'democráticos' se definen fórmulas únicas para prevenir y abordar la violencia contra las mujeres, desconociendo la identidad personal y colectiva de las mujeres originarias. Violencia que se conjuga como una segunda tipología: la violencia interna o propia, de la cual el pueblo mapuche mantiene prácticas que obstaculizan la libre participación y autonomía de las mujeres, niñxs y con ello, el kvme mogen [buen vivir] del pueblo mapuche" (Mercado Catriñir et al. 2015: 5).

20 Los ül, cantos, de estas poetas aparecieron por primera vez transcritos en mapudungun y traducidos al castellano hacia fines del siglo XIX y comienzos del XX, en los estudios realizados por Rodolfo Lenz, Tomás Guevara, Félix de Augusta, Manuel Manquilef y Berta Koessler, entre otros. En la actualidad, estas autoras fueron incluidas en la antología crítica Kümedungun / Kümewirin. Antología poética de mujeres mapuche (siglos XX-XXI) (2010). 
Doralisa, la serpiente Kai-kai, la Pincoya y la Shumpalla ${ }^{21}$ y, por supuesto, Wangülen ${ }^{22}$, la representación alegórica de la primera mujer mapuche.

Sin duda no alcanzo, por ahora, a nombrarlas a todas. Sin embargo, quisiera detenerme en una de las figuras que cruza todo el texto y que ya adelantamos: la Malinche o "Malincha". En ella, la autora proyecta una analogía con la madre Marina a nivel nominal y simbólico, al mismo tiempo que la sujeto de los poemas es también la Malinche: "Malinche me llamaron" (14). Así, la Malinche es el presagio principal de la enunciación. Se trata de una política de filiación que funciona, junto a la significativa imagen "vi los códices arder", como una iteración, ya que ambos sentidos del discurso -la Malinche y los códices- reiteran, una y otra vez, el proceso reivindicativo de una mestizada: el "yo" de la sujeto en comunidad. Además, opera como el punto de partida de aquella memoria ancestral que trae la revelación de una "desgracia” en el presente. Por eso la sujeto es kallku y no machi, una kallku que no solo se posiciona dentro de la sociedad mapuche, sino que sale de ella en búsqueda de un origen vapuleado por la historia oficial -indígena y no indígena- de América Latina:

vi los códices arder

Malinche me llamaron
pero quién supo
de mis ardores
mis nebulosas líquidas mazorcas atorando mi alma
la entraña mía, restallando amarga insidia y miel
del equívoco desvarío (14)

De esta forma, cabe preguntarse: ¿Quién es esta Malinche que nos señala Adriana Pinda y en relación a qué la convoca en su libro? Es decir ¿cuáles son los sentidos que nos trae la figura de Malitzin en el poemario? En esta perspectiva existen varios aspectos, pero, por ahora, me abocaré a revisar solo algunos. Me interesa, en estos momentos, pensar la Malinche pindariana desde la construcción política del sujeto en el sentido que lo plantea Arendt (1993), es decir, a partir de la condición humana más necesaria: la condición política. Es esta la que supone una práctica social y discursiva activa donde cada sujeto no solo hace visible su particularidad y su diferencia, sino que, a la vez, radicaliza "la única libertad posible, la libertad subjetiva" (Zapata 2006: 507). La Malinche pindariana se proyecta, así, como un territorio político en dos direcciones: una, debido a que se configura como un espacio de rastreo e identificación

21 Esta nominación corresponde a una feminización de Shumpall. En términos generales, Shumpall se refiere, dentro de los relatos orales mapuches, a un sujeto mitológico con identidad sexual ambigua y que habita en las aguas. Se cuenta que rapta jóvenes para llevarlas a vivir con él en las profundidades del agua, a cambio de beneficiar a la familia de la joven con una vasta producción de frutos marinos.

22 Kai-kai: serpiente que representa las fuerzas del agua. La Pincoya es un relato oral chilote-huilliche que cuenta la historia de una mujer que vive en el mar junto a sus padres. Su cuerpo está parcialmente vestido con algas. Su presencia sobre una roca o danzando en una playa con la cara vuelta hacia el mar es señal de que en ese lugar la pesca será abundante para los pescadores. Si su orientación es hacia la costa, es indicio de que la pesca será escasa. También ayuda a los náufragos, llevándolos hasta el barco fantasma: el Caleuche, donde revivirán como tripulantes en una nueva existencia. A diferencia de la Sirena, la Pincoya no posee cola de pez, sino que su cuerpo es completamente humano. Wangülen: existen diversas variaciones de la historia de Wangülen. Una de ellas es que se trataría de la primera mujer mapuche. 
de relaciones de dominio; otra, porque se localiza como una subjetividad excluida que socializa y reclama su singularidad dentro de una comunidad que comparte su misma diferenciación. Quiero señalar con esto que, a través de esta representación política de la Malinche, se revela uno de los pilares fundamentales de sujeción y al cual ya nos hemos referido: el contrato entre patriarcados que facilitó la colonización del cuerpo de la mujer indígena. Contrato que, además, en su influjo inmediato, construía a "la mujer indígena", como un espacio pasivo y/o como una "tabula rasa"; de forma similar, hay que agregar, a la toma de posesión del territorio y las tierras americanas, por parte de los europeos. De aquí, entonces, que la sujeto de Parias zugun establezca una alianza estratégica con la figura de la Malinche, en cuanto denuncia la violencia de un origen histórico que pone en marcha "su estirpe” mestiza y paria. Además, de este modo puede legitimar, en el presente, esta conciencia mestiza (Anzaldúa 1999) y su propio territorio de exclusión. Este lugar de alianzas políticas se enfatiza aún más si comprendemos que aparte de posicionar el "yo" en la voz de esta Malinche, simultáneamente, la sujeto se asume en el posible papel de "hija de la Malinche". ${ }^{23}$ Esto tiene dos orientaciones que se imbrican. Por un lado, está el guiño con la madre, Marina, -madre "real" de la sujeto del poemario y también mestiza-, lo que se traduce en un acuerdo identitario tanto de género como de etnia. Y, por otro lado, se establece como metáfora de una deshonra, de una desgracia -vergüenza- ancestral que proviene de su cuerpo colonizado ${ }^{24}$ :

\author{
tú la desterrada \\ en su propia cavidad \\ sin nombre \\ [...] \\ dime
}

¿dónde irás a esconder tu vergüenza? (47)

De esta manera, la voz que la autora asume en su libro se localiza en una sujeto de la "traición", es la sujeto producida por los discursos patriarcales y colonialistas con el objetivo, precisamente, de convertir este lugar de dominación en espacio de reconocimiento y denuncia. Es un territorio identitario que la autora resemantiza cuidadosamente, para emprender el trayecto ético de su diferencia y del que le habla su propio presagio, aquel que nace desde que vio "los códices arder"25. La sujeto es, entonces, la hija de la "traidora” y la "traidora” misma a la vez, ambas como metáforas de aquella india que fue dada como donativo al conquistador al momento de instalarse en territorio americano. La sujeto de Adriana Pinda, por una parte, se ha hecho cómplice de la Malinche, una Malinche que conoce el tamaño de su felonía al

23 Margo Glantz (1992) afirma que escritoras mexicanas como Elena Garro, Rosario Castellanos y Elena Poniatowska se han sentido provocadas y perseguidas por la figura de la Malinche, de igual forma que lo hace ahora Adriana Pinda. Glantz las llama "Las hijas de la Malinche" como "contra respuesta" a lo que Octavio Paz denominara "Los hijos de la Malinche", para referirse indiferenciadamente a los mexicanos en general.

Nótese aquí que el guiño corresponde a la mujer colonizada. No olvidemos que la Malinche es bautizada por Cortés con el nombre cristiano de Marina. Cortés se encuentra con ella por primera vez alrededor de 1520, cuando le fueron entregadas como obsequio, por hombres indígenas, veinte mujeres para su servicio. Entre ellas, se encontraba la Malinche. Luego, Cortés se la cede al capitán Juan Jaramillo para que se case con ella. 
patriarcado y, por lo mismo, reconoce la dimensión de su culpa, lo que le ha generado el castigo de la exclusión. Por otra parte, la Malinche también es resultado de uno de los instrumentos de subordinación más antiguos en las sociedades patriarcales: el tráfico de mujeres (Rubin 1986) y donde la mujer es vista como un producto que beneficia social y políticamente a los hombres ${ }^{26}$. Además, queda al descubierto que:

En una historia masculinizada donde se entremezclan los héroes de un lado y del otro en un confuso panorama de proezas, aquello que queda sumergido y oculto es la relación entre colonialismo y patriarcado. Quedan ocultas las continuidades entre las instituciones patriarcales pre-coloniales y el papel que jugaron en el proceso de consolidación de la conquista y largo colonialismo (Galindo 2015: 36).

Ante la construcción patriarcal y colonialista de una Malinche que representa un origen negativo y femenino-pasivo de la condición mestiza de América Latina, y a partir de la cual se explicaría la derrota indígena ante las huestes españolas durante la conquista, especialmente en México, Adriana Pinda nos ofrece la desestabilización de esta medida de la "verdad histórica". Lo fundamental en este sentido es lo mencionado más arriba y que tiene que ver con el posicionamiento de la sujeto como "hija" o producción de este entronque de poderes "colonopatriarcales”27. Por lo mismo, entonces, la voz enunciativa es la "hija de la Chingada”, de una madre vulnerada, sí, pero que es consciente de su desgracia y no pasiva como se pretende que la concibamos. ${ }^{28}$ Esta conciencia es la que mueve la voz de los poemas hacia el retorno a ese origen, para potenciarlo no como justificación de un sujeto mestizo producto de una violación sin más ni más, sino como la potencia de una catástrofe en cuanto conocimiento de sí misma y no como el adoctrinamiento proveniente de ideologías hegemónicas que apelan al repudio de una "madre" flemática y violada. Esta perspectiva, colonialista y misógina, impone una situación pasiva no solo de la india, sino que de las sociedades indígenas en su versión de “vencidas”.

26 "Las reglas matrimoniales mapuches estaban dominadas por las condiciones de guerra a que estaba sometida su sociedad. El sistema de intercambio generalizado de mujeres tendía a asegurar dos cuestiones fundamentales: un alto nivel de reproducción de la población y la posibilidad de sellar alianzas militares. Es por ello que los mapuches defendían la poligamia como un elemento central de organización de su sociedad. Un cacique con diez mujeres podía llegar a tener más de cincuenta hijos, numerosos mocetones ligados en forma directa al cacicazgo, y una gran cantidad de posibilidades de alianzas políticas” (Bengoa 2000: 131).

27 Sabemos que la configuración del sujeto es un proceso complejo y heterogéneo, puesto que es imposible hacernos de experiencia fuera del poder. Tal como lo afirma Judith Butler (2001), el poder no es solo atributo inevitable en la experiencia del sujeto, sino que, al mismo tiempo, forma parte de su "reflexividad", comprendida esta como un volverse hacia sí mismo en una relación activa que dé cuenta de una formación y una práctica de la conciencia. De esta forma, la construcción de sujeto tiene a lo menos un doble sentido debido a que la misma hegemonía del poder es ambivalente, ya que junto con disciplinar y subordinar, igualmente produce al sujeto.

28 Un ejemplo de estos discursos es el que esgrime Octavio Paz a comienzo de los años 50 en El laberinto de la soledad, ensayo en el cual se establece una directa relación femenino-pasivo que se proyecta a América Latina y que finalmente sería, según el autor, lo que permitió la violación territorial: "Lo chingado es lo pasivo, lo inerte y lo abierto, por oposición a lo que chinga, que es activo, agresivo y cerrado. El chingón es el macho, el que abre. La chingada, la hembra, la pasividad, pura, inerme ante el exterior. La relación entre ambos es violenta, determinada por el poder cínico del primero y la impotencia de la otra [...] La Chingada es aún más pasiva. Su pasividad es abyecta: no ofrece resistencia a la violencia [...] Esta pasividad abierta al exterior la lleva a perder su identidad: es la Chingada. Pierde su nombre, no es nadie ya, se confunde con la nada, es la Nada. Y sin embargo, es la atroz encarnación de la condición femenina. Si la Chingada es una representación de la madre violada, no me parece forzado asociarla con la conquista, que fue también una violación” (Paz 1981: 85 y 94). 
De este modo, y, finalmente, ante la pregunta que nos hacíamos acerca de ¿quién es la Malinche pindariana o cuáles son sus sentidos en el discurso?, podemos comprender que su significación se encuentra en su función micropolítica, la que se proyecta hacia la deconstrucción de poderes hegemónicos que han fundado a la sujeto del texto. Sin duda que una probable respuesta no se ubica en una definición, sino en una aproximación que nos entrega referencias acerca de una posición y legitimación política de la sujeto y su comunidad mestiza, la que tiene un origen histórico de violencias. Por lo mismo, a Adriana Pinda no le interesa la tarea de rescatar su valor “original” de sujeto indígena, sino que más bien su desafío poético supone la ruptura con los estereotipos seculares establecidos sobre la Malinche, como momento inaugural de un tejido genealógico. Tejido matrifilial en el que se representan las contradicciones y las legitimaciones de una experiencia insiliada, y que tiene como consecuencia una existencia paria que solo puede reconstruirse a través de la palabra social y culturalmente "contaminada”.

Por su parte, la imagen que mencionamos antes: "vi los códices arder”, y que junto a la figura de la Malinche funciona como una iteración dentro del texto, nos enfrenta, por lo menos, a dos articulaciones del discurso. Una, en la cual nos encontramos con el brutal hecho histórico en que fueron quemados, por "sacrílegos y demoníacos”, un sinfín de códices mayas y aztecas ${ }^{29}$, es decir, se materializa el imaginario imperial de América como espacio geográfico exento de historia. Otra, en que la misma sujeto de los poemas se posiciona como testigo presencial de este acontecimiento inaugural. Es el momento en que se inicia la irrecuperable pérdida de antiguos procesos de la memoria y del conocimiento prehispánico. En otras palabras, se trata de la desaparición simbólica de una comunidad, pero que se arraiga como un territorio reclamado a partir del cual la sujeto de los poemas comienza el trayecto de emancipación de lo extraviado:

\author{
porque \\ solo la ausencia es el mudo celaje que reina \\ -vi los códices arder- \\ [...] \\ me vuelva la palabra entonces \\ la que buscas \\ en el marrón sortilegio de unos ojos \\ -inche ta zugun- diré \\ -inche ta wall mapu- \\ -yo soy la palabra \\ yo soy el mundo- (117-118)
}

\footnotetext{
La primera quema de códices se produjo en 1530 en Texcoco, cuando el franciscano Juan Zumárraga lanza a la hoguera un sinnúmero de manuscritos aztecas. Más tarde, en 1562, otra quema de códices se produce a cargo de otro franciscano, Diego de Landa. Luego de que un grupo de indígenas fueran sometidos a interrogatorios y torturas en un tribunal religioso dependiente de la Inquisición, Diego de Landa, en un auto de fe, desata la imposición de su catolicismo quemando, entre otras producciones culturales indígenas, los códices mayas, de los que solo se salvaron tres.
} 
Es así como en Parias zugun esta colectividad silenciada o extraviada se transforma en una "comunidad emancipada", la que obviamente no permanece inmóvil o fosilizada en el tiempo, sino que se rearticula para contener a la sujeto en su presente. De esta forma, se materializa el sentido plural de la identidad mestiza y de los vínculos solidarios - la comunidad-, que en ella actúan. Por esta razón, la protagonista, al tiempo que es una sujeto actual, es también su propia ancestro. Ella misma es parte de la visión de su presagio, es la que tiene el doble sentido de ir hacia atrás y de retornar al presente pasando, sin duda, por el trayecto fundamental de la experiencia política de su identidad mixturada. De esta forma, Adriana Pinda, al recuperar una memoria subterránea, está invocando la mancha, la cicatriz histórica y cultural producto no solo de la estocada colonial, sino también indígena. Se trata de un "entronque patriarcal” que se articula, de otras maneras, al presente de la voz del poemario.

La patriarcalización del poder en el texto de Pinda es el escenario que delimita el lugar material e intelectual de la mujer mestiza-indígena (Cumes 2012). La problemática del destierro interno y obligado que nos presenta la autora interpela un contexto histórico de subordinación a través del tiempo, develando en un presente la función segregadora que este tiene al momento de entender y organizar su propia estructura cultural. Esta misma estrategia de sujeto discriminada le permite a la voz enunciativa apostar por la construcción de sujetos colectivos no ensimismados en la etnicidad, sino que creadores de nuevas formas de vida que pueden actuar sobre las miradas etnocentristas, y que además reafirman la condición mestiza de la sujeto. Basta con revisar nuevamente la genealogía comunitaria diversa que teje la sujeto y con poner atención, a modo de ejemplo, en las siguientes imágenes utilizadas en el texto: "la Trafianada" y "la willichada" (20). Ambas expresiones dan cuenta, a la vez, de una castellanización del mapudungun -en sus terminaciones, con la intención de posicionar un colectivo que interviene con cierta fuerza en un lugar-, y de una reafirmación en la filiación identitaria-territorial mapuche:

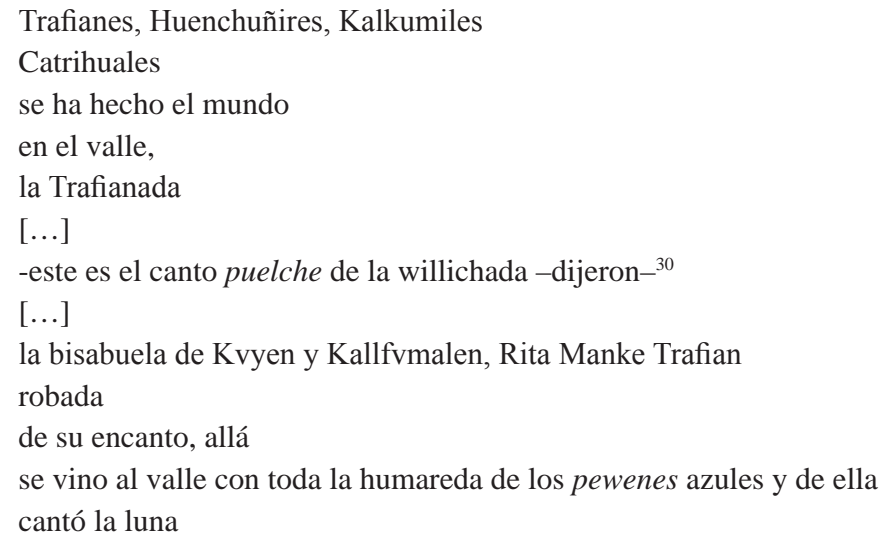

\footnotetext{
Las expresiones Trafianes (de Trafian), Huenchumires (de Huenchumir), Kalkumiles (de Kalkumil) y Catrihuales (de Catrihual) representan la colectivización simbólica de apellidos -nombres antiguamente-, mapuche. De igual modo, sucede con willichada, solo que aquí se refiere a la sociedad williche. Esta colectivización le asigna fuerza comunitaria y disruptiva a ciertos fragmentos sociales y territoriales de los mapuche.
} 
bajó la primera estrella, Wangülen nacería así el ombligo del mundo Riñinahue $(20-21)^{31}$

Vemos aquí que el sentido comunitario con que la sujeto interpela al sistema se posiciona no en un eje marginal o en un desvío, sino que, por el contrario, se trata de un centro nodal -“ombligo”- desde donde, además, se establece una fundación simbólica de la sociedad mapuche: Wangülen. Asimismo, se está dando cuenta de que la comunidad perdida de la sujeto es una comunidad política, porque justamente no está olvidada ni silenciada, sino que recuperada, cargada de sentido. Esto, en tanto que la sujeto vuelve -por una voluntad política- no solo a tener lo que antes poseía, sino que también a través de la reparación de esta comunidad expoliada, restablece y posiciona una condición mestiza-indígena individual y colectiva.

La figura de la Malinche corresponde, también, a este mismo proceso de reconstrucción comunitaria, ya que es restituida dentro de un colectivo excluido por alianzas patriarcales y coloniales. La Malinche pindariana, de esta forma, es asumida a partir de su contradicción como sujeto histórica, es decir, a partir de lo que justamente el poder colonial-patriarcal cancela al suponerla en un solo marco histórico, ya sea como víctima, sujeto subversivo o como aliada del poder imperial (Martínez-San Miguel 2008).

\section{AlREDEDOR DE LA PARIA PINDARIANA}

Sabemos ya que la voz poética que nos propone Adriana Pinda corresponde a una sujeto excluida por su condición mestiza. En esta perspectiva, la posición que asume la sujeto se emplaza a partir de una política de la vergüenza: "la vergüenza de ser esta y no la otra" (97). Esto significa que la sujeto se apropia de su deshonra mestiza, la que, a su vez, le traza un camino hacia el destierro interno: "que no me sienta en la palpitación de mi desgracia” (97). Esta doble estrategia de la vergüenza, es decir, su apropiación y su degradación, pone de manifiesto su plural alcance político. En efecto, el texto alude a una política de la vergüenza que se relaciona con la reivindicación que la sujeto realiza de su derecho a ser mestiza. Sin embargo, y al mismo tiempo, el poemario desenvuelve la sanción política de la vergüenza, porque nos refiere a la dificultad del reconocimiento. El argumento en este sentido es que la sujeto, en tanto mestiza, no puede complacerse de la igualdad, si no es en función de su similitud con la comunidad dominante que construye los criterios de reconocimiento (Vera 2014: 78). Por lo tanto, la voz poética es capaz de hacer dialogar los conflictos y las contradicciones de su experiencia en la medida en que construye su diferenciación como experiencia y no como codificación identitaria. De ahí que la sujeto presente una escisión dialógica entre una y otra: “Ah mujer mía / te leo / [...] ¿ ¿Qué será de ti?” (105).

31 La alusión a Riñinahue se articula con la identidad territorial de la misma autora, puesto que actualmente es machi del lof o comunidad "Kallfüllanka" ubicada en Riñinahue, comuna de Lago Ranco, en la Región de Los Ríos. Es necesario mencionar que la producción poética de Adriana Pinda podría situarse como una escritura "autógrafa”, puesto que siempre está estableciendo vínculos con su propia experiencia de sujeto "empírico". 
La reivindicación de la conciencia mestiza y la problemática del reconocimiento que acabamos de mencionar permiten, además de aproximarse al complejo proceso de ser una y otra a la vez, visualizar la subjetividad exiliada de la sujeto:

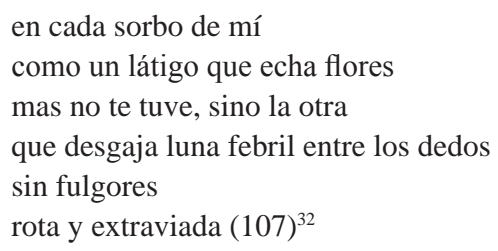

Esta conciencia de sí misma como sujeto desdoblada y extraviada abre la posibilidad de que tome para sí el atributo de paria. A partir del título del libro, Parias zugun, habría una señal, una marca lingüística que, a mi juicio, correspondería al complejo posicionamiento de un habla champurria que la sujeto utiliza a su favor como lugar y movimiento de resistencia a la exclusión y a la vergüenza. Se trata de una palabra que se sitúa en una frontera de intercambios lingüísticos y donde la sujeto establece su primera filiación política: el habla "contaminada" de una sujeto expatriada. Una paria, “[...] categoría de excluido(a)s obligados a tomar del pensamiento dominante una gran parte de las nociones y referencias con las que formula su revuelta contra la exclusión” (Varikas 1995: 81). Fundamental, entonces, es el uso del lenguaje, ya que la selección y la refacturación lingüística en el texto, tanto del castellano como del mapudungun, favorecen la comprensión de las implicancias subjetivas que la sujeto posiciona. Es esta una cuestión esencial, puesto que es a partir de esta elaboración del discurso que la sujeto procesa su conciencia mestiza y desde la cual emergen los sentidos políticos y simbólicos revisados anteriormente. Es través de esta conciencia además, que la sujeto nombra y realiza el montaje y desmontaje de su condición y de los poderes que entran en juego en ella:

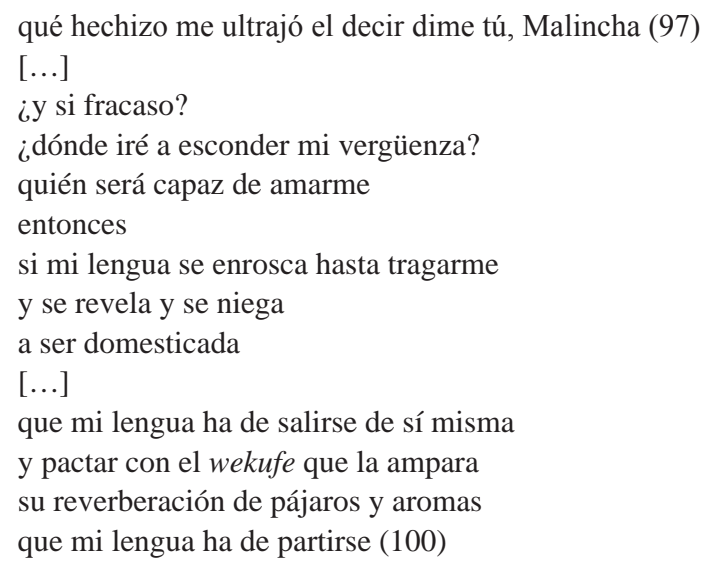

\footnotetext{
Este fragmento corresponde a un poema que, sin duda, es un diálogo explícito con el poema "La otra" de Gabriela Mistral que aparece abriendo su libro Lagar de 1954. El diálogo se da fundamentalmente con Lucila y no con Gabriela. Por lo mismo, podríamos deducir, y de forma muy general, puesto que podría indagarse aún más en esta intertextualidad, que la apelación simbólica que hace Adriana Pinda es a la sujeto que Mistral asesina en el poema: "una en mí maté", y que en una lectura en clave "biográfica" se trataría de Lucila, la que literariamente podría ser la mestiza.
} 
Notamos aquí cómo las interrogantes se multiplican hacia todos los espacios de configuración identitaria que hemos planteado para esta sujeto pindariana. Me refiero a la mestiza en la figura de la Malinche, a la lengua partida que se niega a ser reprimida, a la identificación con el wekufe y a la vergüenza mestiza. Sin embargo, la estrategia central del poema está situada en un habla que se bifurca entre la pérdida y el préstamo, y donde la lengua mapuche emerge como una falta y un desasosiego. Esta carencia y este malestar se manifiestan como un deseo amoroso que irrumpe cada vez que la sujeto asume una lengua rota. Hablamos de un retorno al mapudungun, aunque sea por momentos, a través del pewma, de la memoria, de visiones o de presagios:

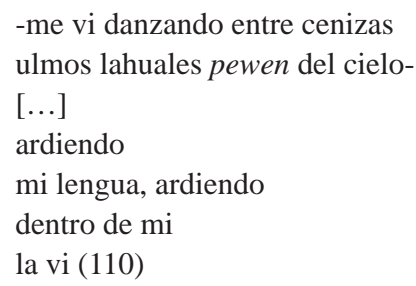

La condición de paria de la sujeto, es consecuencia de su existencia y habla champurrias. Esta última, el habla, corresponde a la expresión de un lenguaje propio que se alimenta de un caudal de experiencia, de subjetividad y de identidad, incluyendo la producción de afectos, de resistencias, de contradicciones, de conocimientos y pensamientos que emergen de este caudal. El habla que nos propone Pinda no se reduce a una comunicación lingüística de subversión ante una normalización cultural, sino que se complementa con una vinculación espacial-telúrica que involucra un territorio. Aquí se arraiga su comunidad elegida, la que afirma su existencia y que podríamos decir, se conforma como una matria mestiza ${ }^{33}$, la que actúa como espacio político de socialización y reivindicación. En este ejercicio se localiza una producción de saberes que provienen de su decir teñido y, por lo mismo, múltiple y abyecto, con el que reclama una reflexión omitida: el intraexilio obligado de la mestizada.

De aquí, como decíamos, escoge para sí, es decir, para su condición de mestizamapuche y por consecuencia para su lengua, el atributo de paria. En relación a lo que acabo de señalar, me interesa seguir la lectura que realiza Eléni Varikas (1995) acerca de la figura paria ${ }^{34}$. En primer lugar, entonces, la protagonista de Parias zugun se construye como sujeto paria porque alberga el perfil hereditario de la exclusión (Varikas 1995); ya lo veíamos con la figura de la Malinche y otras menciones que se hacen en el texto. Se trata de una característica que se subraya en las relaciones o filiaciones que establece con otro(a)s sujetos ancestrales, históricos, actuales y con figuras simbólicas de la literatura o de relatos de origen mapuche. En un segundo lugar y como resultado de esta comunidad de filiación, la sujeto recoge el signo

\footnotetext{
Tomo el término matria de Llanca Marín, quien lo utiliza para nombrar la "matria mapuche". Al respecto dice: "Se habla de reconstruir la 'patria' Mapuche y ¿quién dice que debe ser patria - pater? El seno de nuestra existencia es la Mapu Ñuque, la madre tierra, nuestra MATRIA y nuestro espacio físico es el wallmapu".

34 Recojo lo planteado por Varikas, puesto que ella plantea la figura del paria como una posibilidad de las mujeres, fundamentalmente en el siglo XIX, para pensar su condición de excluidas "no solo como un destino biológico, sino que también como una situación social impuesta por el derecho del más fuerte, como una injusticia” (1995 81).
} 
“impuro” y “contaminado” -y contaminante- que conduce su exclusión:

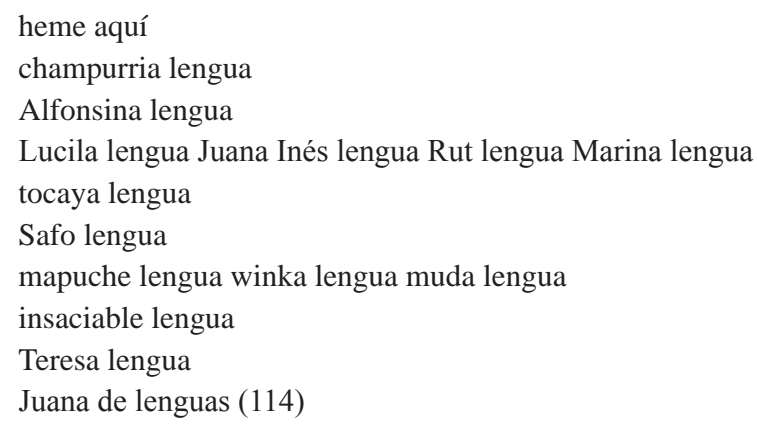

El uso que la autora da a la metáfora de "lenguas parias” o parias zugun obtiene su impulso de un contenido semántico de interpelación que va en contra de la violencia del exilio forzado, el que es resultado de una política discriminatoria actual que sienta sus bases en una perspectiva esencialista del sujeto mapuche. Ante esta hegemonía vemos que existe un tono substancial, en el sentido que Pinda le asigna a la imagen de la paria. Nos referimos a la valoración de aquello por lo que la sujeto sabe que es excluida su mestizada. Una valoración que se da por una posición de legitimidad que asume la sujeto individual y colectiva, y que se sitúa voluntariamente dentro de la comunidad que la rechaza. Este sentido del valor no se funda en la comunidad de individuos que la discrimina a partir de una micropolítica reetnificacionista, sino que está en el imaginario cultural y espiritual de la sociedad mapuche, el que conforma el contenido medular del mapudungun. Contenido que, claro está, tiene movilidad en cuanto es una lengua viva:

Que Genechen ${ }^{35}$ habla en che sungun ${ }^{36}$, dicen sus maestros.

Te busco entre mis muertos resplandecientes

te lamento en esta tierra baldía, Liftray

mi lucero

el que apaciguó las raíces del pewen en mi pelo

-“lucero de nieve prematura”- me dijeron en lenguas (82)

Por esta misma razón es que su lengua, y por eso también su subjetividad, su conocimiento y su deseo habitan en un territorio fronterizo de alimentación afectiva, intelectual y cultural de legitimación y resistencia. De esta forma, el valor concedido a la sujeto paria del texto es una propuesta ética que se traduce en dignidad; es decir, la vergüenza se convierte en dignidad. La vergüenza de la paria pindariana se transforma en una alteridad de valores con los que la sujeto se enfrenta y vive la exclusión. De esta forma, me parece que esta sujeto se acerca a lo que Pilar Castro comenta en torno a la figura paria propuesta por Eléni Varika:

\footnotetext{
Chau Genechen es uno de los espíritus más relevantes de la religión tradicional mapuche. 
el paria, figura de abyección social y política, encarna, al mismo tiempo, una crítica social y una rebelión contra la injusticia. [...] [la] singularidad de la experiencia humana del paria como otredad radical [...] expone la dificultad de concebir la diversidad y pluralidad como partes esenciales de [cualquier] sistema [social, político y cultural] (Castro, en Varika 2011: 123).

El paria o la paria en el caso del poemario de Pinda gestiona su propio lugar para habitar, donde la sujeto elabora un tejido lingüístico con el que va a representar su alteridad. He aquí entonces el habla paria, y no solo eso, sino que en plural como nos advierte el libro: parias zugun. Con este habla diverso y en el que, principalmente, entran en juego el mapudungun, el che zungún y el castellano ${ }^{37}$, la sujeto despliega el espacio para la enunciación y materialización de su subjetividad de expatriada y de la dignificación de su vergüenza. Vemos, por ejemplo, que este sentido del lenguaje se construye, dentro de muchas otras elaboraciones lingüísticas, con los siguientes adjetivos: lengua paria, lengua enloquecida, lengua huacha, lengua champurria, lengua amalgama, lengua arpía, lengua bruja, lengua demonio y lengua errante, entre otras. Esto se origina no en una simple adjetivación, sino que tiene su contenido en la experiencia de la misma sujeto, en las diferentes subjetividades de la comunidad que ha escogido y, sobre todo, en la elaboración de un discurso poético contestatario ante la injusticia que recae sobre ella y su colectividad. De esta manera y siguiendo el discurso de Varikas, quien habla a partir de sus lecturas de Hannah Arendt, ${ }^{38}$ la sujeto paria va a dejar ver una doble filiación de experiencia: de frustración y de rebeldía.

El primero de los casos se relaciona con el fracaso, el que se deriva de la problemática del destierro de la sujeto y la complejidad de establecer una comunidad política a partir de un proyecto de inclusión, que finalmente no puede llevar a cabo debido a la fuerza del poder histórico que la discrimina. En el siguiente fragmento advertimos este fracaso de la sujeto, es decir, su frustración frente a la imposibilidad de algún retorno al universo mapuche:

\author{
Kallfullanka ${ }^{39}$ \\ olvidada y muda por cien años \\ con mis dedos abrí tu boca \\ y desgarré \\ el ultrajado susurro \\ de tus dientes (74)
}

37 Aquí se advierte que, al parecer, hay una intención implícita de comunicar que la lengua dominante en el poemario es el castellano, porque las palabras en mapudungun aparecen en cursiva. Quizás sea esta una doble estrategia política del discurso. Por un lado, denunciar una realidad colonialista que perdura hasta hoy, asumiendo una posición colonizada, como "realidad" de la sujeto poética, y que se constituye en el eje de su mestizaje; por otro lado, la consciente localización de su deseo: la "lengua amor" como le llama la sujeto al mapudungun. Y como el deseo siempre es una interrupción a la norma, este sería parte de la rebeldía, por lo tanto, formaría parte de una política discursiva descolonizadora.

38 Para Hannah Arendt existe el "paria consciente". Se trata de aquel sujeto que abraza la realidad política de su condición y que reclama y construye un territorio donde sea factible la práctica de su libertad, desafiando la estructuración oficial del mundo (Rayas Padilla 2011). 
El segundo, relacionado con la rebeldía, corresponde a la resistencia que manifiesta la voz enunciativa, la que se condice con la posición diferenciada, radical y heteronómica que asume la sujeto (Varikas 2011). Justamente, para esta protagonista poética la experiencia heteronómica es la que le provoca la insubordinación ante los supuestos normativos que se fundan en un esencialismo mapuche, en relación a la construcción de identidad:

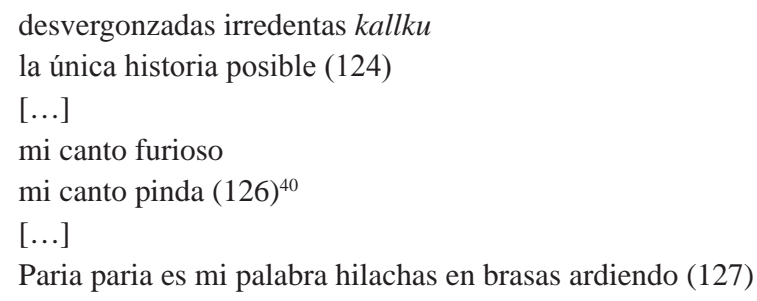

La paria pindariana es una elaboración aporética de la diferencia, la que da cuenta de una desviación de lo cultural y socialmente correcto para una normativa tradicionalista del pueblo mapuche y también, para la sociedad chilena que desea un sujeto indígena pasivo en sintonía con la imagen del "buen salvaje”. En este sentido, en ambas sociedades se trata de miradas hegemónicas, las que resuelven qué es "igual" y qué es "diferente". Estas prácticas oficiales de la identidad elaboran la igualdad o el "sí mismo" como una soberanía, instalando "lo mestizo" no como un contenido identitario de "diferenciación" que aporta a una sociedad diversa producto de procesos históricos, sino como fundamento racial de la exclusión.

En la medida en que el mestizaje se presenta como una condición de vida de la sujeto de los poemas, la contradicción existencial que plantea Adriana Pinda se hace inevitable y legítimamente compleja. De hecho, esta sujeto paria experimenta su “diferencia” y su "similitud”, en relación a la sociedad y cultura mapuche, como un rechazo (Vera 2014: 79). A través de esta problematización del proceso de identidad, es que la protagonista posiciona una política de la experiencia, ya que se preocupa de articular la subjetividad a la ambivalencia de un habla contestataria. Esta voluntad reivindicativa significa que a la paria de Pinda no le interesa desvincular su propia experiencia de exclusión del “conjunto de las relaciones sociales injustas” (Varikas 2007 cit. en Vera 2014: 81). Se trata de una sujeto que asume su condición de paria como consecuencia de su mestizaje impuesto, es decir, la voz enunciativa sabe -está enterada- bajo qué fronteras se ha construido y se construye; por lo tanto, reconoce que la "mismidad” y la "diferencia” dentro de la sociedad mapuche han producido su contradicción.

Estamos, entonces, ante el posicionamiento político de una diferenciación voluntaria y cuidadosamente trabajada. Esta identificación con la alteridad de una mestizada paria, se vuelve consciente en cuanto sabe que su cometido es negociar políticamente la pertenencia de la sujeto y su comunidad al cuerpo social mapuche. Tal negociación solo se puede materializar, primero, en la medida que la sujeto pone al descubierto el contrato de poder histórico entre el patriarca y el colonizador y que ha determinado el origen de su exclusión, más su actual estado de depreciación.

$40 \quad$ Pinda: picaflor. 
Segundo, en la medida que la sujeto presenta su propia demanda de justicia. Y, finalmente, apropiando su "vergüenza" en dignidad en pos del reconocimiento de una experiencia diferenciada.

\section{COMENTARIOS FinALES}

Es necesario, a nuestro parecer, comenzar estas reflexiones finales comprendiendo que la noción de sujeto no puede entenderse fuera de los poderes hegemónicos. Sin embargo, simultáneamente entendemos que el sujeto también es un lugar donde es posible la elaboración de saberes y conocimientos que facultan la exploración crítica y afectiva de formas diferenciales de representación e integración social. Solo así, pensamos, podemos ubicarnos ante la voz discursiva que nos entrega Adriana Pinda en Parias zugun. Como sujeto mapuche-mestiza, la sujeto del poemario se vincula a propósitos emancipatorios y dignificantes de su condición identitaria, por lo tanto sitúa su voluntad y conciencia en itinerarios propios de identificación. A partir de esto, escoge y construye un tejido de subjetividades que se articulan a su propia vergüenza mestiza y a su trayecto de paria. Este tejido se alimenta de las aportaciones de una genealógica familiar y ancestral mapuche, de una narrativa de origen, de la poesía mapuche -especialmente de mujeres- y de la literatura occidental -fundamentalmente, la poesía de mujeres-. De este modo, el volver a indagar en las imágenes y significaciones de figuras como la Malinche, Kalku, wekufe o Kanillo, permite aproximarnos a una lectura no totalizadora y/o mitificadora, no solo de las sociedades mapuche o indígenas, sino también latinoamericanas. Asimismo, nos permite resignificar historias culturales y conocer ciertos mecanismos en la dinámica de las relaciones de poder, en cuanto a la producción de una subjetividad desplazada.

Como ya he propuesto a lo largo de este artículo, la sujeto poética de Adriana Pinda se enfrenta a la posibilidad de pensar su condición mestiza no solo como una condición social y cultural impuesta ya desde un contrato patriarcal y colonial, sino como lo que he querido llamar "políticas de la vergüenza y la exclusión”. Con esto quiero decir que la sujeto pindariana, al configurarse también como un sujeto político, produce diferentes iniciativas de resistencia. Una de ellas es el intento de dar a la "vergüenza mestiza" y a su correlato de exclusión un sentido de dignidad y contestatario. De esta forma, se interrumpe la sujeción de significados históricos, alterando, de manera ética y creativa, las normativas culturales -pasadas y presentesde pertenencia a una sociedad determinada.

Estamos al tanto de que estas políticas discursivas expuestas en Parias zugun, son el resultado de un reconocimiento de las estrategias de dominio del sistema patriarcalcolonial. Me refiero aquí, no tan solo a la desmitificación que realiza la sujeto de los relatos de origen que regulan a la sociedad mapuche, sino también, a la apropiación de otros elementos históricos oficiales que la obligan a sentirse ajena a una comunidad. Es en este sentido, que la filiación con la figura de la Malinche le proporciona, a la voz poética, una herramienta de interpretación crítica que le ayuda a comprender su posición dentro de lo instituido. De aquí, entonces, lo que ya decíamos: Pinda señala y denuncia una comunidad acallada, pero no por eso inexistente, $\mathrm{y}$, por lo mismo, se convierte en una comunidad escogida y reivindicada, justamente, porque se trata de una red de sentidos políticos que garantizan una subjetividad mestizada y de resistencia. 
Como consecuencia de este actuar político de restablecer lo que se le ha quitado o negado, la sujeto desenvuelve una conciencia del propio "yo" y del nosotros diferenciado. De esto se deduce que la autora apela a una "individuación” (Olivera 2013), proceso que para Pinda es un recorrido largo. No solo debe atravesar por la sociedad mapuche, sino también por su propia “envidia”, por la familia, los ancestros, los relatos de origen, la poesía -mapuche y no mapuche-, el habla, la lengua y la violencia histórica -el patriarcado y el colonialismo- y la vergüenza; y, fundamentalmente, por su experiencia de exiliada y paria interna. En este sentido, habría que decir que el exilio intracultural e intraterritorial propuesto en el libro se plantea como parte de la identidad de la sujeto, por lo tanto, se transforma en condición identitaria que se mantiene en interdependencia con su condición mestiza. En otras palabras, la sujeto no deja ni va a dejar de ser, aunque retorne o aunque sea aceptada por la comunidad dominante, una insiliada mestiza, porque ya es parte de su experiencia vital. Pensamos, en esta perspectiva, que si bien un/a sujeto desplazado/a puede repatriarse y participar de la cultura y la sociedad de la que fue discriminado/a, nunca vuelve a estar en el lugar de origen del cual fue expulsado/a. Es más, me parece que en el caso de la sujeto mestiza pindariana este lugar inaugural nunca ha existido, ni antes, ni durante ni después de la violencia histórica, social y cultural a la que ha sido sometida, porque, además, no forma parte de la historia heroica y fundadora del sujeto mapuche originario. Por lo tanto, la palabra paria y su nodo comunitario serían la única posibilidad de lo propio que aparece en la sujeto, en cuanto condición de desplazada y mestiza.

Para la poeta no hay individuación -no hay “yo”, no hay “zugu”- sin reconocer y recuperar un colectivo. De este modo, hay que comprender que en la poética pindariana se mantiene una perspectiva indígena-mapuche de la comunidad, y que tiene que ver con la solidaridad y las redes filiales de protección, tanto las heredadas como las apropiadas. El libro completo está en clave mestiza en su más amplia acepción, sin embargo, se trata de un texto poético evidentemente mapuche, en el cual la ambivalencia es parte constitutiva del sujeto mestizo-mapuche que allí se presenta. Se trata de una sujeto inestable, porque se localiza en un deseo mapuche de igualdad, pero en situación de marginalidad en cuanto a su representación política no olvidemos que es kallku y no machi-, y, además, culturalmente es mestiza. Es por esto que la metáfora, no tan solo de un habla paria, sino que también de una sujeto y una comunidad expatriada en su propio territorio social y cultural, se convierten en una estrategia de sentido compensatorio y de autovaloración que demanda, para la sujeto poética, la dignidad de su proceso de identidad.

Tanto la comunidad extraviada como la comunidad reconstruida que nos pone en escena Adriana Pinda, es políticamente sospechosa: traiciona tanto una historia oficial latinoamericana, a través de la figura de la Malinche, como una estabilidad cultural mapuche, sobre todo al asumir la voz de kallku y realizar un küpalme mestizo. Sin embargo, la interpelación al presente de marginación que experimenta la sujeto es una pieza clave, puesto que deja al descubierto, simbólicamente, las estructuras esencialistas actuales que predominan en parte de la sociedad mapuche.

En esta perspectiva, no olvidemos que, actualmente, el pueblo mapuche experimenta, por razones históricas, la radicalización de una subjetividad "militante”. Subjetividad que tiene como resultado lo que Pairicán llama "mapuchismo” y que coincide con lo que Morley denomina "esencialismo estratégico" (2005). Por lo 
tanto, el "mapuchismo" puede entenderse como un "esencialismo estratégico" que deben mantener sociedades que han visto vulnerados sus territorios, sus identidades, sus derechos y sus autonomías debido a la invasión, el despojo, la colonización y la racialización que han experimentado en diferentes momentos de su historia o a lo largo de su historia ${ }^{41}$. Podemos inferir, entonces, que es en este contexto que la sujeto que nos presenta Adriana Pinda experimenta las consecuencias sociales y culturales de esta estrategia "mapuchista”. Sin embargo, me parece también que este “esencialismo estratégico”, como micropolítica de resistencia, no debe comprenderse como respuesta política a la historia de violencia, sin atender a un contexto patriarcal histórico, tal como lo advierte Lorena Cabnal:

afirmamos la existencia milenaria del patriarcado ancestral originario [en Abya Yala (América)], el cual ha sido gestado y construido justificándose en principios y valores cosmogónicos que se mezclan con fundamentalismos étnicos y esencialismos [actuales]. (Cit. en Gargallo 2014: 80)

Parias zugún no solo explora en esta doble articulación de las relaciones de poder entre un "esencialismo estratégico" y un patriarcalismo atávico, sino que suma una tercera: el colonialismo sobre la mujer indígena. En el texto se encuentra, de este modo, un discurso contra-patriarcal, contra-colonial y contra-etnocentrista, que pondera los territorios de contacto, las identidades transversales y los espacios heterogéneos; asumiendo, si se quiere, una política del mestizaje con una importante localización de género. En nuestra perspectiva, el poemario brinda una comprensión acerca de que la única posibilidad de construir una reflexión y una conciencia de identidad, no puede darse en los extramuros de este triple maridaje de poderes. Aquí, lo relevante es cómo Adriana Pinda problematiza estas tres dimensiones del poder a la hora de configurar las políticas de identidad que están en juego. Para esto, la autora inscribe una cartografía de poder propia que opera como una "política de dislocación”, la que contiene y fortalece las políticas de la vergüenza y la exclusión, y que se relaciona con qué significa habitar territorios diferenciados de la identidad y cuáles serían las posibles formas de pertenencia que se pueden establecer en un espacio contemporáneo (Morley 2005).

Pienso que una propuesta en este sentido tiene que ver con que es a partir de esta representación política de la vergüenza y de la exclusión de "lo mestizo", representación muchas veces dificultosa y ciertamente ética, donde pueden generarse nuevos conocimientos críticos y nuevos saberes estéticos. Finalmente, entonces, el interés político de mi lectura de Parias zugún en estos momentos es comprender e imaginar este espacio mestizo como un lugar complejo y diverso, con préstamos y negociaciones culturales que van de un lado a otro, donde los bordes fronterizos son porosos y no menos problemáticos. Con esto quiero decir que el texto se configura como un espacio de saberes de y en responsabilidad crítica, respecto de procesos identitarios diferenciados. En este sentido, pienso también en lo que nos propone la feminista chicana Gloria Anzaldúa, y que viene a reafirmar la apuesta mestiza y paria

41 El caso de los mapuche es emblemático en este sentido, de aquí el complejo conflicto político-histórico que existe hoy entre el Estado-gobiernos chilenos y el pueblo mapuche. Para revisar una "historia corta" de las causas históricas que han llevado al pueblo mapuche a esta legítima demanda política, ver José Bengoa (2000, 2012). Para una mayor profundización al respecto, revisar Pablo Marimán et al. (2006) y Fernando Pairicán (2014). 
de Adriana Pinda: “[y] si ir a casa me es denegado entonces tendré que levantarme y reclamar mi espacio, creando una nueva cultura -una cultura mestiza- con mi propia madera, mis propios ladrillos y argamasa” (1999: 46) ${ }^{42}$. Por lo mismo, me parece que para Adriana Pinda nunca es una redundancia insistir en la necesidad de una validación de aquello que conocemos como “justicia simbólica”. Esto involucra una posición ética-política en torno a qué individualidad queremos ser y qué comunidad queremos construir-pertenecer.

\section{OBRAS CITADAS}

Anzaldúa, Gloria. 1999. Borderlands / La frontera. The new mestiza. San Francisco: Aunt Lute Books.

Arendt, Hannah. [1958] 1993. La condición humana. Barcelona: Paidós.

Bhabha, Hommi.2002. El lugar de la cultura. Buenos Aires: Manantial.

Bengoa, José. 2000. Historia del pueblo mapuche (siglo XIX-XX). Santiago: Lom Ediciones. . 2012. "Los mapuche: historia cultural y conflicto". Cahiers des Amériques Latines 68. https://cal.revues.org/118. 19 de nov. de 2015.

Bourdieu, Pierre. 1989. "El campo literario. Prerrequisitos críticos y principios de método". Criterios 25-28: 20-42.

Brah, Avtar. 2011. Cartografías de la diáspora. Identidades en cuestión. Madrid: Traficantes de sueños.

Butler, Judith. 2001. El género en disputa. El feminismo y la subversión de la identidad. España: Paidós.

Carrasco, Hugo. 2005. “Adriana Pinda: luces de estrellas arcaicas”. Crítica situada. El estado actual del arte y poesía mapuche. Temuco: Universidad de la Frontera. 117-132.

Centro de Investigaciones y Defensa Sur (CIDSUR). "Tribunal oral en lo penal de Valdivia condena a machi Millaray Huichalaf y absuelve a tres defensores del 'kintuante'. http:// cidsur.cl/2014/11/tribunal-oral-en-lo-penal-de-valdivia-condena-a-machi-millarayhui-chalaf-y-absuelve-a-tres-defensores-del-kintuante/. 2 de feb. de 2016.

Cumes, Aura Estela. 2012. "Mujeres indígenas, patriarcado y colonialismo: un desafío a la segregación comprensiva de las formas de dominio". Anuario Hojas de Warmi 17: 1-16. http://revistas.um.es/hojasdewarmi/article/viewFile/180291/151201. 15 de junio de 2015.

De Augusta, Félix. Lecturas Araucanas. Valdivia: Imprenta de la Prefectura Apostólica, 1910.

Deleuze, Gilles y Guattari, Félix. 1994. Mil mesetas. Capitalismo y esquizofrenia. Valencia: Pre-Textos.

Foucault, Michel. 1992. El orden del discurso. Buenos Aires: Tusquets Editores.

Galindo, María. 2015. "La revolución feminista se llama Despatriarcalización”. En Ochi Curyel y María Galindo (Eds.). Feminista siempre. Descolonización y despatriarcalización de y desde los feminismos de Abya Yala. España: ACSUR. 27-50.

García, Mabel. 2012. "El proceso de la retradicionalización cultural en la poesía mapuche actual: Üi de Adriana Pinda”. Revista Chilena de Literatura 81: 51-68.

Gargallo Celentani, Francesca. 2014. Los feminismos desde Abya Yala. Ideas y proposiciones de las mujeres de 607 pueblos en nuestra América. Ciudad de México: Editorial Corte y Confección.

Guevara, Tomás. 1911. Folklore Araucano. Santiago de Chile: Imprenta Cervantes.

Glantz, Margo. 1992. "Las hijas de la Malinche". Debate Feminista, 6: 161-179.

Hooks, Bell. 2004. "Choosing the margin as a space of radical openness”. En Sandra Hard-

42 Las cursivas pertenecen al original. 
ing. The feminist standpoint theory reader. Intellectual and political controversies. New York-Londres: Routledge. 152-159.

Koessler-Ilg, B. 2006a. Cuenta el pueblo mapuche, V. I, Santiago: Editorial Mare Nostrum. 2006b. Cuenta el pueblo araucano, V. II, Santiago: Editorial Mare Nostrum. 2006c. Cuenta el pueblo araucano, V. III, Santiago: Editorial Mare Nostrum.

Lenz, Rodolfo. 1895-1897. Estudios araucanos. Santiago de Chile: Imprenta Cervantes.

Mansilla, Sergio. 2011. "Sobre el sujeto lírico mestizo: una aproximación a la subjetividad en la poesía de las memorias culturales”. Revista Chilena de Literatura, 78: 69-90.

Manquilef, Manuel. 1911. Comentarios del pueblo araucano. Santiago de Chile: Imprenta Cervantes.

Marimán, Pablo et al. 2006. ¡...Escucha winka...! Cuatro ensayos de Historia Nacional Mapuche y un epílogo sobre el futuro. Santiago: Lom Ediciones.

Marín, Llanca. 2004. "La matria mapuche y el patriarcado occidental". Mapuexpress. http:// www.ecoportal.net/Temas-Especiales/PueblosIndigenas/La_Matria_Mapuche_y_el_Patriarcado_Occidental. 5 de agosto de 2015.

Martínez-San Miguel, Yolanda. 2008. “¿Hacia unos estudios coloniales globales?: entrecruces, aportes, limitaciones”. En Lucía Melgar (comp.). Persistencia y cambio: acercamiento a la historia de las mujeres en México. México: El Colegio de México. 55-77.

Mercado Catriñir, Ximena et al. 2015. Yamuwvn mu ka poyen tañi ixofij mogen amuleay tañi kvme mogen. Con respeto y amor por las distintas vidas, avanzamos hacia el buen vivir. Temuko: Corporación de Mujeres Mapuche Aukinko Zomo. http://www.mapuexpress. org/wp-content/uploads/2016/03/Sistematizacio\%CC\%81n-de-Nvxamkawvn.pdf. 9 de marzo de 2016.

Mistral, Gabriela. 1997. Lagar. México: Editorial Porrúa.

Moraga, Fernanda. 2006. “Adriana Pinda y el habla escrita de la ajenidad: 'Relámpago'. Alpha 23: 117-136.

2009a. "Filigranas poéticas/asedios nómades a la poesía de mujeres mapuche y de origen mapuche”. Nomadías 9: 225-257.

. 2009b. “A propósito de la diferencia: poesía de mujeres mapuche”. Revista Chilena de Literatura, 74: 225-239.

2012. Autoproducción de subjetividades fronterizas en la poesía actual de mujeres mapuche. Tesis doctoral inédita. Santiago: Universidad de Chile.

2013 "Políticas del cuerpo y subjetividades fronterizas en el libro Shumpall de Roxana Miranda Rupailaf”. Nomadías 17: 9-34.

Mora Curriao, Maribel y Moraga-García, Fernanda. 2010. Kümedungun / Kümewirin. Antología poética de mujeres mapuche (siglos $X X-X X I)$. Santiago: Lom Ediciones.

Morley, David. 2005. "Pertenencias: Lugar, espacio e identidad en un mundo mediatizado". En Leonor Arfuch (comp.). Pensar este tiempo. Espacios, afectos, pertenencias. Buenos Aires: Editorial Paidós. 129-168.

Nómez, Naín. 2010. "Exilio e insilio: representaciones políticas y sujetos escindidos en la poesía chilena de los setenta”. Revista chilena de Literatura 76: 105-127.

Olivera, Mercedes. 2013. "Mercedes Olivera y la construcción de feminismo indígena". Entrevista. Cimacnoticias. http://www.cimacnoticias.com.mx/node/65278. 14 de agosto 2015.

Paredes, Julieta. 2013. Hilando fino. Desde el feminismo comunitario. México: E1 Rebozo, Zapateándole, Lente Flotante, El cortito qu's palargo y Alifem AC.

Paredes, Julieta y Guzmán, Adriana. 2014. El tejido de la rebeldía ¿Qué es el feminismo comunitario? La Paz: Comunidad Mujeres Creando Comunidad.

Pairicán, Fernando. 2013. "Lumaco: la cristalización del movimiento autodeterminista mapuche”. Revista de Historia Social y de las Mentalidades 17. 1: 35-57.

. 2014. Malón. La rebelión del pueblo mapuche 1990-2013. Santiago: Pehuén Editores. 
Paz, Octavio. 1981. El laberinto de la soledad. Postdata. Vuelta al laberinto de la soledad. México: Fondo de Cultura Económica.

Pinda, Adriana. 2000. "Ralum”. Pentukun 10-11: 197-220. 2001. "Williche, poetas y poesía. Nosotros como el sol no tenemos amanecer". En Pilar Álvarez-Santullano y Almilcar Forno (eds.). Fütawillimapu. Osorno: Universidad de Los Lagos-CONADI. 105-113.

. 2004-2005. "Witral ñi rayen / La flor del telar". Ciudad Circular. Revista de Creación Horizontal 5: 8-11. 2005. Üi. Santiago: Lom Ediciones.

2014. Parias zugun. Santiago: Lom Ediciones.

2014. “Cartas al país mapuche”. En Virginia Vidal (Ed.). Anaquel austral. Santiago: Editorial Poetas Antiimperialistas de América. http://virginia-vidal.com/anaquel/article_583.shtml. 13 de mayo de 2015.

Quidel Lincoleo, José. 2015. "Del por qué y cómo fueron violentados y sobrepasados los mapuche en su pensamiento y espiritualidad”. En Enrique Antileo Baeza, et al. (Eds.). Awükan ka kuxankan zugu wajmapu mew. Violencias coloniales en Wajmapu. Temuco: Ediciones Comunidad de Historia Mapuche. 37-53.

Rayas Padilla, Estela Jacqueline. 2011. El concepto de paria en la obra de Hannah Arendt. Guadalajara: Universidad de Guadalajara.

Rubin, Gayle. 1986. "El tráfico de mujeres: Notas sobre la 'economía política' del sexo". Revista Nueva Antropología, vol. VIII, 30: 95-145.

Spíndola, Jorge. 2011. "Poesía mapuche, memorias y fronteras culturales. Adriana Paredes Pinda y Liliana Ancalao, dos poetas mapuche contemporáneas”. Memorias del Coloquio Colonialidad/Decolonialidad del Poder/Saber. Valdivia: Universidad Austral. 67-73.

Varikas, Eléni. 1995. "Paria: una metáfora de la exclusión femenina”. Política y Cultura, 4: 81-89.

. 2011. "Los desechados del mundo: imágenes del paria”. Andamios, vol. 8, 16: 123136.

Vera, Antonieta. 2014. "Vergüenza y estrategia: figuras 'parias' en América Latina”. Cuestiones de filosofia, 16: 77-88.

Zapata, Guillermo. 2006. “La condición política en Hannah Arendt”. Papel político, vol. 11, 2: 505-523. 